\title{
FLUID AND MINERAL INCLUSIONS AND INCLUSION ZONES OF CAVE CALCITE FROM KORSNÄS MINE, WESTERN FINLAND
}

\author{
PENTTI REHTIJÄRVI and KARI A. KINNUNEN
}

\begin{abstract}
REHTIJÄRVI, PENTTI and KINNUNEN, KARI A. 1979: Fluid and mineral inclusions and inclusion zones of cave calcite from Korsnäs Mine, western Finland. Bull. Geol. Soc. Finland 51, 75-79.

Inclusions and crystal forms of calcite crystals from a cave in the Korsnäs lead-lanthanide mine in western Finland have been studied. The primary fluid inclusions in the scalenohedral yellowish calcite show homogenization temperatures of $79^{\circ}$ to $103^{\circ} \mathrm{C}$ and salinities of 3.6 to 4.9 eq. wt. $\% \mathrm{NaCl}$. The prevailing crystal form is scalenohedron. In some specimens it reveals a rhombohedral phantom. Four mineralization stages are proposed on the basis of correlation between inclusion zones in multiple-zoned calcite crystals.
\end{abstract}

Pentti Rehtijärvi and Kari A. Kinnunen, Geological Survey of Finland, SF-02150 Espoo 15, Finland.

\section{Introduction}

During mining operations in the Korsnäs lead-lanthanide mine (closed 1972), situated about $30 \mathrm{~km}$ south of the town of Vaasa in western Finland, a cave was found $190 \mathrm{~m}$ below the earth's surface (Tuominen 1961). The cave $(0.5 \mathrm{~m} \times 1.5 \mathrm{~m} \times 30 \mathrm{~m})$ is part of a vertical fracture zone. Its walls were partly covered by euhedral crystals of calcite, harmotome, apophyllite, pyrite and apatite; the main mineral was calcite. A small amount of euhedral quartz and ancylite was also found. Apophyllite and harmotome have been described by Sahama (1965) and Sahama and Lehtinen (1967). An age of $88 \mathrm{Ma}$ was determined for yellow apophyllite by the
K/Ar-method (Dr. Eric Welin, written communication in 1975). The isotopic composition of the galena indicates an age of 1770 $\mathrm{Ma}$ for the sulphide ore (Isokangas 1975).

The cave mineralization was studied by collecting information from the fluid and mineral inclusions of different zones in individual calcite crystals. On the basis of the mode of occurrence of the inclusions an inclusion »stratigraphy» was established that is comparable to the sphalerite "stratigraphy» described by Roedder (1977) as a result of a study of sphalerite zoning and paragenesis at Creede, Colorado. The calcite »stratigraphy» established gives an overall view of the cave mineralization in the Korsnäs mine. 


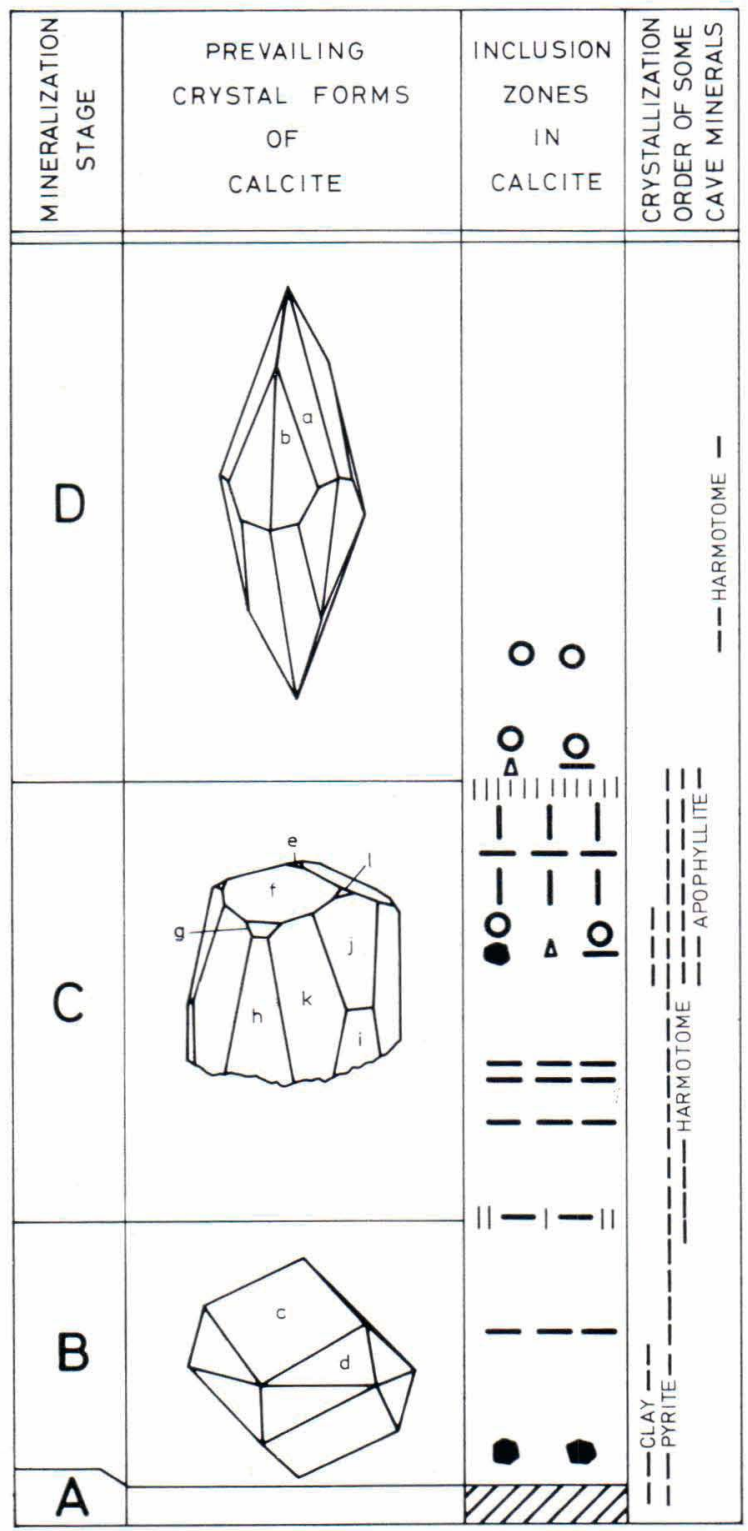

PROPOSED INDICES FOR

THE CRYSTAL FACES OF

CALCITE :

$\begin{array}{llll}\mathrm{a} & (121) & \mathrm{g} & (302) \\ \mathrm{b} & (511) & \mathrm{h} & (100) \\ \mathrm{c} & (101) & \mathrm{i} & (010) \\ \mathrm{d} & (883) & \mathrm{j} & (041) \\ \mathrm{e} & (001) & \mathrm{k} & (561) \\ f & (102) & \mathrm{l} & (011)\end{array}$

EXPLANATION FOR THE

INCLUSION ZONES IN CALCITE:

- PRIMARY FLUID INCUSIONS

III PSEUDOSECONDARY FLUID INCUSIONS

I - PYRITE

$\Delta \quad$ APOPHYLLITE

- Redeposited clay

WD MONTMORILLONITE - CHLORITE CLAY LAYER

Fig. 1. The proposed mineralization stages, prevailing crystal forms of calcite, inclusion zones in calcite and the suggested crystallization order of the main cave minerals.

\section{Materials and methods}

Thirty euhedral calcite crystals, varying in length from 2 to $7 \mathrm{~cm}$, were examined. Calcite shows parallel growth, and most of the specimens exhibit scalenohedral morpho- logy. Some of these yellowish translucent scalenohedrons contain a white pyrite-covered rhombohedral phantom marking the earlier growth stage of the crystal. Individual rhombohedral calcite crystals were also found. A few of the calcite crystals are 
yellow and either transparent or translucent. The transparent crystals are characterized by a basal plane. In some crystals the pyramidal faces are curved. The three prevailing crystal forms are depicted in Fig. 1.

The homogenization temperatures of the fluid inclusions were determined with a Leitz 350 heating stage and a Chaixmeca microthermometry apparatus. The Chaixmeca stage was also used for the freezing point determinations. The temperature readings were calibrated with organic melting point standards. The accuracy of the temperature measurements was $\pm 2^{\circ} \mathrm{C}$, at $50^{\circ}$ to $150^{\circ} \mathrm{C}$, and $\pm 0.1^{\circ} \mathrm{C}$ at $-5^{\circ}$ to $0^{\circ} \mathrm{C}$.

\section{Mineralization stages}

The cave mineralization was divided into four stages on the basis of the mineral paragenesis and the prevailing crystal forms of calcite (see Fig. 1). Mineralization stage A is characterized by the crystallization of montmorillonite-chlorite clay, stage $\mathrm{B}$ by the crystallization of rhombohedral calcite and pyrite, stage $\mathrm{C}$ by the crystallization of scalenohedral calcite, harmotome and apophyllite and stage D by the crystallization of yellowish scalenohedral calcite. The crystallization order of the cave minerals was inferred from the mineral inclusion zones in calcite crystals, the mineral crystallizing in the cave often having been trapped inside growing calcite.

\section{Inclusion zones}

The crystal habit of pyrite is distinct and hence characteristic in the different inclusion zones of the proposed mineralization stages (Fig. 1). This observation was utilized in correlating the fluid inclusion zones found in individual calcite crystals. In mineralization stage $\mathrm{A}$ the pyrite inclusions simulate a cube; in stage $B$ they are elongated cubes. The calcite generation of mineralization stage $\mathrm{C}$ contains pyrite inclusions showing parallel growth. The oldest pyrite generation in this mineralization stage is a cube whose growth started with the formation of the (112) crystal face. In the following zones of stage $\mathrm{C}$, pyrite exhibits parallel growth along the triad axis. The habit of pyrite in the fifth and sixth inclusion zones is similar to that of the first. The youngest pyrite of stage C shows parallel growth along the triad axis. The pyrite in the youngest calcite from stage $\mathrm{D}$ is combination of a cube and a pentagonal dodecahedron.

Apophyllite and clay are found in three different inclusion zones (Fig. 1). Primary fluid inclusions were usually formed in these zones when pyrite, apophyllite or clayey material disturbed the growth of the crystal faces of calcite. Calcite crystals of similar habit have similar outermost inclusion zones, which confirms their contemporaneous crystallization.

Pseudosecondary fluid inclusions characterize two of the inclusion layers situated between the mineralization stages. At the end of stage B white calcite with a rough surface had crystallized over the rhombohedron in a layer about $0.5 \mathrm{~mm}$ thick that was found to contain appreciable pseudosecondary fluid inclusions. Before the youngest calcite generation crystallized, a fracture layer about $0.2 \mathrm{~mm}$ thick developed on some of the faces of the calcite crystals. Pseudosecondary fluid inclusions are abundant in these fractures as well.

\section{Fluid inclusions}

The primary fluid inclusions in calcite were found to be concentrated in specific inclusion 


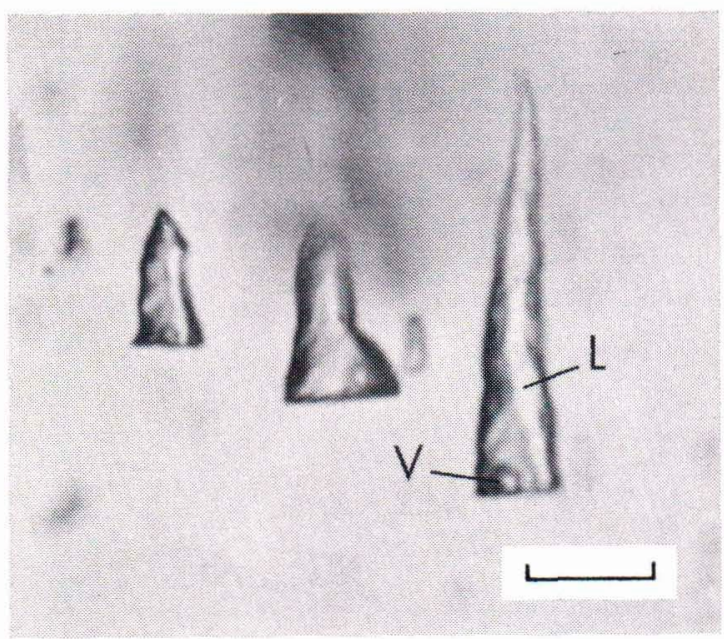

Fig. 2. Photomicrograph of typical primary fluid inclusions with liquid (L) and vapour (V) in yellowish scalenohedral calcite; homogenization temperatures $92^{\circ} \mathrm{C}, 93^{\circ} \mathrm{C}$ and $88^{\circ} \mathrm{C}$; freezing temperatures $-2.4^{\circ} \mathrm{C},-2.4^{\circ} \mathrm{C}$ and $-2.3^{\circ} \mathrm{C}$ corresponding to salinities of $4.5,4.5$ and 4.3 eq. wt. $\%$ NaCl. Transmitted light, one nicol, bar length $10 \mu \mathrm{m}$.

zones (Fig. 1). At room temperature these inclusions usually consisted of liquid and a small bubble of vapour; in stage D, however, the primary fluid inclusions often contained only liquid. At room temperature the inclusions are metastable (cf. Roedder 1971).

The shape of the primary fluid inclusions tend to resemble the crystal form of the host calcite (negative crystals, Fig. 2). Some of these primary inclusion cavities are as much as $1 \mathrm{~cm}$ long in stage D. The inclusions with a length of over $150 \mu \mathrm{m}$ were almost always leaked as a result of fracturing.

The homogenization and freezing temperatures were measured from the primary fluid inclusions embedded in the scalenohedral calcite of mineralization stage D (see Fig. 1 for location). The homogenization temperature of about 100 inclusions was $79^{\circ}$ to $103^{\circ} \mathrm{C}$, with the maximum frequency at $90^{\circ}$ to $95^{\circ} \mathrm{C}$. All these inclusions homogenized to liquid. The freezing temperature of 17 inclusions was $-1.9^{\circ}$ to $-2.7^{\circ} \mathrm{C}$, corresponding to a salinity of 3.6 to 4.9 wt. $\% \mathrm{NaCl}$ equivalent. During cooling many of the inclusions decrepitated when ice was crystallized at about $-50^{\circ} \mathrm{C}$.

The homogenization temperature of about 600 secondary fluid inclusions in the calcite of mineralization stages $\mathrm{B}$ and $\mathrm{C}$ ranges from $50^{\circ} \mathrm{C}$ to about $80^{\circ} \mathrm{C}$. In addition, microcracks have been found to radiate from some of the primary fluid inclusion cavities of mineralizing stage D. These cavities contain secondary fluid filling with a freezing temperature of about $0.0^{\circ} \mathrm{C}$.

\section{Conclusions}

The study of fluid and mineral inclusions of 30 euhedral calcite crystals from a cave in the Korsnäs mine shows that the inclusion zones in individual multiple-zoned calcite crystals can be correlated. The crystallization order of the main cave minerals could also be inferred from the inclusion zones in calcite. The prevailing calcite crystal form is yellowish scalenohedron which in some specimens reveals a white rhombohedral pyrite-covered phantom. The mode of growth of calcite and pyrite has varied in different mineralization stages, and inclusions are usually located in the zones where the calcite habit has changed. Homogenization temperatures of primary fluid inclusions varied from $79^{\circ}$ to $103^{\circ} \mathrm{C}$.

The homogenization temperatures obtained allow the following estimates to be made for the formation temperature under different pressure conditions in a 5 -percent $\mathrm{NaCl}$ solution (Potter 1977, Fig. 2): 200 bar $110^{\circ}$ $130^{\circ} \mathrm{C}, 400$ bar $130^{\circ}-150^{\circ} \mathrm{C}, 1000$ bar $170^{\circ}$ $190^{\circ} \mathrm{C}$, and 2000 bar $235^{\circ}-255^{\circ} \mathrm{C}$. The authors consider the pressure estimate from 200 bar to 400 bar to be the most probable because of the low solubility of calcite at 
temperatures above $150^{\circ} \mathrm{C}$ (cf. Holland 1967). Our estimate for the formation temperature is, therefore, between $110^{\circ}$ and $150^{\circ} \mathrm{C}$. Thus, we suggest endogenic heat derivation because the geothermal gradient alone cannot explain the rise in temperature if the fluid pressure was near hydrostatic. According to the K/Ar age determination ( $88 \mathrm{Ma}$ ), the heat deriva- tion might be attributed to Cretaceous tectonic movements.

Acknowledgements - The authors thank Mr. Reino Himmi, M.Sc., Professor Th. G. Sahama and Dr. Ilmari Haapala for their support. Our thanks are also due to Professor Eric Welin for the age determination of apophyllite. Mrs. Gillian Häkli has corrected the English.

\section{References}

Holland, H. D. (1967) Gangue minerals in hydrothermal deposits. Pp. 382-436 in Geochemistry of hydrothermal ore deposits, ed. by Barnes, H. L.; Rinehart and Winston Inc., New York.

Isokangas, P. (1975) The mineral deposits of Finland. Phil.Lic-thesis, Dept. of Geology, University of Helsinki, $128 \mathrm{p}$.

Potter, R. W., II. (1977) Pressure corrections for fluid-inclusion homogenization temperatures based on the volumetric properties of the system NaCl- $\mathrm{H}_{2} \mathrm{O}$. U.S. Geol. Survey Jour. Research 5, 603-607.
Roedder, E. (1971) Metastability in fluid inclusions. Soc. Min. Geol. Japan, Spec. Issue 3, 327-334.

- (1977) Fluid inclusions as tools in mineral exploration. Econ. Geol. 72, 503-525.

Sahama, Th. G. (1965) Yellow apophyllite from Korsnäs, Finland. Mineral. Mag. 34, 406415 .

- and Lehtinen M. (1967) Harmotome from Korsnäs, Finland. Mineral. Mag. 36, 444-448.

Tuominen, H. (1961) Outokumpu Oy, Korsnäsin kaivos. English summary. Vuoriteollisuus 19 (2), $23-33$.

Manuscript received, April 11, 1979 